\title{
Zwierzchnicy rosyjskiej administracji górniczej w Królestwie Polskim
}

abstrakt: Artykuł przedstawia reformy struktur administracji przemysłu górniczego na zachodnich kresach Imperium Rosyjskiego, a dokładniej w Królestwie Polskim. Autorzy charakteryzują okoliczności, w jakich podporządkowano miejscowe organy administracji górniczej ministerstwu finansów Imperium Rosyjskiego, a następnie opisują dalsze zmiany struktury, prawa i podziału terytorialnego tej administracji. Kluczową częścią artykułu jest prezentacja zwierzchników administracji górniczej Królestwa Polskiego.

sŁowa KLUCzowe: Imperium Rosyjskie, Królestwo Polskie, XIX wiek, przemysł górniczy, administracja górnicza, aparat urzędniczy, biurokracja.

\section{Administracja specjalna i administracja górnictwem w Królestwie Kongresowym}

Zabieg teoretycznego wydzielania jakiegoś przedmiotu obserwacji, opisu i badań powinien przynosić określone korzyści, nową jakość. Nie ulega wątpliwości, że proces rzeczowej specjalizacji, czy też komplikacji struktury władzy wykonawczej, zarówno na szczeblu centralnym - co nazywamy resortowością - jak i terenowym takiej klasyfikacji wymaga. Widzimy więc ewolucyjne wyodrębnianie i rozwój kolejnych wyspecjalizowanych organów ze skoncentrowanych organów administracji ogólnej. Zachodzi on zazwyczaj szybciej na szczeblu centralnym, stąd dla opisu zjawiska w terenie posługujemy się elastycznym i stopniowalnym pojęciem zespolenia administracji, a problematyka ta była przedmiotem żywego 
zainteresowania już w opisywanej epoce ${ }^{1}$. Mimo to teoretyczne, a nawet praktyczne wydzielenie administracji specjalnej od ogólnej dla wieku XIX jest zadaniem skomplikowanym ${ }^{2}$. Administracja w znaczeniu podmiotowym to różnego rodzaju jednostki organizacyjne (organy administracji publicznej, zakłady administracyjne, przedsiębiorstwa państwowe). Wszystkie one administrują w znaczeniu funkcjonalnym, czyli wykonują funkcje administracji publicznej ${ }^{3}$. Przy czym administrowanie działalnością nastawioną na zysk wnosi do administracji bardzo konkretne kryterium oceny administrowania, czego biurokraci, mówiąc kolokwialnie, nie lubią. Właśnie taka gałąź administracji będzie przedmiotem tego artykułu. W tym wypadku mamy dodatkowo do czynienia z przejściem między dwoma ustrojami politycznymi, prawnymi i administracyjnymi Królestwa Polskiego i Imperium Rosyjskiego ${ }^{4}$.

Powoływanie wyspecjalizowanych organów władzy i całych nowych resortów było następstwem kilku zjawisk. Przede wszystkim było reakcją na nieraz burzliwy rozwój działalności człowieka $\mathrm{w}$ danej dziedzinie i związany z nią rozwój nauki i techniki. Oczywiście bezpośrednią przyczyną była wola monarchy, oparta na świadomości i woli jego doradców. Wszystkie wyżej wymienione czynniki spotykamy, badając powstanie i rozwój administracji górnictwem w Królestwie Polskim. Tutaj należy podkreślić, że w omawianym okresie dział górniczy nie ograniczał się jedynie do kopalnictwa - wydobycia kopalin (węgla, rud, soli, wód mineralnych itd.) - ale obejmował też hutnictwo i przemysł metalurgiczny, a łączono z nim także zarządzanie lasami górniczymi i produkcję węgla drzewnego.

Nie ma potrzeby, aby wspominać tu całą historię górnictwa w Polsce. W Królestwie Polskim postanowieniem namiestnika 20 II 1816 r. powołano w Kielcach Dyrekcję Główną Górniczą, pod nadzór której oddano państwowe i prywatne zakłady górnicze ${ }^{5}$. Był to organ kolegialny, podporządkowany wydziałowi górniczemu Komisji Rządowej Spraw Wewnętrznych. W 1827 r. rozporządzeniem Rady

${ }^{1}$ Patrz szerzej: И. А. Блинов, Губернаторы: историко-юридический очерк, Sankt Petersburg 1905.

2 Patrz wstęp do: A. Górak, K. Latawiec, Rosyjska administracja specjalna w Królestwie Polskim, 1839-1918, Lublin 2014.

${ }^{3}$ Patrz szerzej choćby: Prawo administracyjne, red. M. Wierzbowski, Warszawa 2003; E. Ura, E. Ura, Prawo administracyjne, Warszawa 2001.

${ }^{4}$ Patrz: А. Горак, К. Лятавец, Российская специальная администрация Королевства Польского и ее начальники в XIX в., [w:] Управление документацией: прочлое, настоящее и будущее. Материалы II Международной научно-практической конференции. Москва, 19-20 марта 2015 2., red. T. Bykowa, J. Kukarina, J. Skripko, Moskwa 2015, s. 491-500.

${ }^{5}$ Dziennik Praw Królestwa Polskiego (dalej DPKP). T. 1, 1816, s. 169 i n. 
Administracyjnej z 2 (14) XII 1826 r. przeniesiono (zlikwidowano) Dyrekcję do Warszawy i pod nazwą Wydziału Górniczego włączono do struktur Komisji Rządowej Finansów i Skarbu. Niecodziennym posunięciem było oddanie administracji górniczej Bankowi Polskiemu, co stało się postanowieniem Rady Administracyjnej Z 22 III (3 IV) 1833 r. Celem sprawniejszego administrowania górnictwem utworzono specjalny podział administracyjny - podzielono Królestwo na trzy okręgi na czele z naczelnikami: Wschodni z siedzibą w Suchedniowie, Zachodni - w Dąbrowie i Północny - w Ciechocinku. Akt prawny z 23 XI (3 XII) 1842 r. ponownie oddał administrację górnictwem Komisji Rządowej Finansów ${ }^{6}$.

\section{Rosyjska administracja górnicza w Królestwie Polskim}

\subsection{Naczelnicy zarządów okręgów górniczych Królestwa Polskiego}

W drugiej połowie XIX w. Imperium Rosyjskie przyjęło już zdecydowanie kurs rusyfikacyjny, zarzucając pozory imperium uniwersalnego. W historiografii polskiej, bez należytej refleksji nad polityką rosyjską wobec Wielkiego Księstwa Finlandii, guberni nadbałtyckich i Kaukazu, wiąże się nasilenie represji z upadkiem powstania styczniowego i jakoby wyjątkową polityką Imperium wobec polskości. Nie ma tu miejsca na gruntowną krytykę takiego partykularnego podejścia. Ogólnie rzecz ujmując, stopniowo, ale dość szybko, zniesiono autonomię administracyjną Królestwa i rozpoczęto obsadzanie wszelkich stanowisk „urzędnikami pochodzenia rosyjskiego”, począwszy od kierowniczych. Tę szeroko zakrojoną akcję można rozpatrywać nie tylko jako represje czy racjonalne zapewnienie panowania, ale także jako kolonizację Królestwa Polskiego. Wcześniej lub później zdecydowana polityka rusyfikacyjna i kolonizacyjna objęła wszystkie tereny Imperium.

${ }^{6}$ J. Jaros, Organizacja administracji górniczej w Królestwie Polskim (1815-1918), „Studia z Dziejów Górnictwa i Hutnictwa” T. 12, Warszawa 1968, s. 116-139; tenże, Organizacja rzq̨dowej administracji górniczej na Ślasku w latach 1769-1922, „Archeion” T. 26, 1956, s. 187-213; tenże, Stan badań nad historia górnictwa i hutnictwa na ziemiach polskich w latach 1870-1918, „Studia z Dziejów Górnictwa i Hutnictwa” T. 1, 1957, s. 107-128; A. Okolski, Wykład prawa administracyjnego oraz prawa administracyjnego obowiq̨zujacego w Królestwie Polskiem, Warszawa 1882, s. 265-279 (\$ 209); J. Pazdur, Organizacja i polityka górnicza (1772 do 1918 r.), [w:] Zarys dziejów górnictwa na ziemiach polskich, red. J. Pazdur, Katowice 1961, s. 17-38; S. Świętochowski, Ustrój władz górniczych w Królestwie Polskim, Rosji, Niemczech, Austrii, Francji i innych państwach, Warszawa 1918. 
Pierwszym etapem było likwidowanie centralnych organów Królestwa Polskiego i podporządkowywanie miejscowej administracji ministerstwom Imperium Rosyjskiego. Tak więc 16 VI (1 VII) 1870 r. zatwierdzoną przez imperatora ustawą Komitetu ds. Królestwa Polskiego zlikwidowano centralne władze resortowe administracji skarbu Królestwa Polskiego i jednocześnie podporządkowano miejscową administrację przemysłu górniczego departamentowi górnictwa w ministerstwie dóbr państwowych Imperium Rosyjskiego w Sankt Petersburgu. W departamencie tym powołano wydział polskich zakładów górniczych kierowany przez zarządzającego. Było dwóch szefów tego wydziału: od 1 VII 1870 r. do 1 XII 1875 r. [starego stylu, tu i dalej st.st.] Władimir Silwestrowicz Tuczemski (Владимир Сильвестрович Тучемский), a następnie do końca istnienia wydziału (2 XI 1891 r.) Aleksiej Andriej Piotrowicz von Коерреn (Алексей Андрей Петрович Кеппен). Było to rezultatem zachowania odrębnego charakteru administracji terenowej tego resortu w Królestwie. Nadal więc przemysł górniczy na tym terenie podlegał dwóm zarządom okręgowym Królestwa Polskiego - Wschodniemu i Zachodniemu, na czele tych zarządów stali naczelnicy ${ }^{7}$.

Zarząd Wschodniego Okręgu Górniczego (управление восточного горного округа Царства Польского) z siedzibą w Suchedniowie i zarząd Zachodniego Okręgu Górniczego (управление западного горного округа Царства Польского) w Dąbrowie Górniczej nie były, jak wskazuje na to nazwa, organami kolegialnymi, ale urzędami kierowanymi jednoosobowo przez naczelników, którzy bezpośrednio podlegali departamentowi górnictwa (ww. wydziałowi) ministerstwa finansów w Petersburgu. Naczelnikom z kolei podlegali kierownicy kopalń i hut oraz personel techniczny ${ }^{8}$.

Naczelnikami Zachodniego Okręgu Górniczego Królestwa Polskiego byli kolejno (od 1868 r. do 24 IX 1870 r.) Paweł Niechwedowicz (Павел Онуфриевич Нехведович), (od 2 X 1870 r. do 1 XI 1876 r.) Nikołaj Grumm-Grzymajło (Николай Моисеевич Грумм-Гржимайло), a ostatnim - Aleksiej Żukowski

${ }^{7}$ DPKP, 1870, t. 70, nr 249, s. 327-347, O poszukiwaniach górniczych i wydzieleniu przestrzeni do górniczego wydobywania ciał kopalnych; Полное Собрание Законов Российской Империи (dalej ПСЗРИ), собрание II, t. 45, nr 48322, 5 V 1870 r., O przekształceniu organów górnictwa w guberniach Królestwa Polskiego i tymczasowym określeniu liczby i wynagrodzenia stanowisk służbowych zarządów zachodniego i wschodniego okręgów górniczych w Królestwie Polskim; Указатель Правительственных Распоряжений по Министерстве Финансов (dalej УПРМФ), 1870, nr 24, s. 353-356.

8 УПРМФ, 1870, $\mathrm{nr}$ 24, s. 353-356; Zbiór praw, instrukcji i przepisów, obowiąujacych dla prywatnego przemysłu górniczego w guberniach Królestwa Polskiego, oprac. S. Bukowiecki, wyd. K. Srokowski, H. Hoffmann, Dąbrowa 1899. 
(Алексей Николаевич Жуковский), który zresztą nigdy nie został zatwierdzony na tym stanowisku i jedynie pełnił obowiązki naczelnika od 1 XI 1876 r. do 2 VIII $1878 \mathrm{r}$. Tak więc potwierdza to tezę, że w $1876 \mathrm{r}$. likwidacja stanowiska naczelnika Zachodniego Okręgu Górniczego Królestwa była już przesądzona.

Paweł Niechwedowicz urodził się 1834 r. w guberni permskiej. Był wyznania prawosławnego. Studiował w Imperatorskim Instytucie Górniczym w Sankt Petersburgu, który ukończył 12 VI 1853 r. z dyplomem I kategorii i prawem awansu do stopnia porucznika korpusu inżynierów górnictwa. W tym czasie korpus inżynierów górnictwa miał charakter wojskowy. Majątku ziemskiego nie posiadał. Był synem lekarza okręgu niżnietagilskiego (Niżny Tagił - miasteczko powiatowe w guberni permskiej), urzędnika w randze radcy stanu Onufrego Niechwedowicza, syna Ignacego (ur. przed 1790 r. - zm. po 1834 r.). Nazwisko oraz imię ojca i dziadka każą podejrzewać, że Niechwedowiczowie pochodzili z terenów Rzeczypospolitej. Ponadto zapewne tenże Onufry Niechwedowicz w 1811 r. obronił w Wilnie pracę doktorską z medycyny pt. „Observatio medica de rariori lingue vitio organico, quam loco speciminis inauguralis ad assequendum in caeserarea litterarum universitate vilnensi”. . Onufry był jednym z pierwszych absolwentów wileńskiej medycyny i po ukończeniu uniwersytetu dostał „dobrą posadę przy kopalniach uralskich w $1812 \mathrm{r}$. z pensją po $700 \mathrm{rs.} \mathrm{rocznie"10.} \mathrm{Jednak} \mathrm{nas} \mathrm{interesuje} \mathrm{przede}$ wszystkim jego syn Paweł, którego po ukończeniu nauki, 18 VI 1853 r. skierowano do dyspozycji głównego naczelnika zakładów uralskich, a miesiąc później (20 VII 1853 r.) oddelegowano do zajęć praktycznych w zakładzie gorbatowskim, gdzie 21 VII 1854 r. przyjęto go do służby etatowej. Tam 6 X 1854 r. dostał posadę nadzorcy kopalni złota. Po trzech latach (15 VI 1857 r.) przeniesiono go do zakładów ołonieckich. Następnie 1 I 1858 r. został pomocnikiem zarządzającego Aleksandrowskim Zawodem, a 7 IX 1861 r. - zarządzającym. Nie znamy przyczyn, z powodu których 30 VIII $1863 \mathrm{r}$. na własną prośbę został zwolniony ze służby z prawem noszenia munduru. Do służby wrócił dopiero 5 VII 1868 r. i został skierowany do departamentu górnictwa Królestwa Polskiego, gdzie pełnił obowiązki naczelnika Zachodniego Okręgu Górniczego. Podobnie jak Jan Hube, po podporządkowaniu górnictwa Królestwa Polskiego Petersburgowi Niechwedowicz przeszedł do nadzoru nad przemysłem prywatnym - 25 IX 1870 r. został okręgowym inżynierem

${ }^{9}$ Bibliografia Estreicherów, s. 226 [on-line] <https://www.estreicher.uj.edu.pl/> [dostęp grudzień 2017 r.].

${ }^{10} \mathrm{~S}$. Trzebiński, Zarys historii Wileńskiego Instytutu Medycznego, odbitka z „Ateneum Wileńskiego" Z. 12, Wilno 1927, s. 37. 
górnictwa I okręgu nadzoru nad prywatnymi zakładami górniczymi w guberniach Królestwa Polskiego, a jeszcze przed 1 IV 1874 r. - II okręgu. Ostatni znany fakt z jego kariery to zwolnienie 1 IX 1887 r. ze służby z emeryturą i prawem noszenia munduru na własną prośbę. Co ciekawe, ze względu na miejsce urodzenia i wyznanie przysługiwały mu prawa ,urzędnika ruskiego pochodzenia” i w związku z tym otrzymywał od 1873 r. piętnastoprocentowy dodatek do wynagrodzenia za pięć lat służby w Królestwie Polskim. Nie wiemy, kiedy dokładnie zmarł Paweł Niechwedowicz. Na pewno stało się to po roku $1885^{11}$.

Jego następcą był Nikołaj Grumm-Grzymajło (ur. 4 IX 1833 r. w guberni penzeńskiej - zm. 15 IX 1913 r. w Sankt Petersburgu), prawosławny szlachcic dziedziczny guberni mohylewskiej, pochodzący ze szlacheckiego rodu herbu Grzymała, ale dóbr ziemskich nie posiadał. Jego ojcem był Moisiej Grumm-Grzymajło (ur. 26 VII 1794 r. - zm. po 1861 r.), syn Własa (ur. w 1738 r. - zm. 11 XII 1812 r.) i Marianny Burmilewej. Tenże Moisiej był urzędnikiem w randze radcy stanu, który potwierdził swoje szlachectwo herbu Grzymała w Heroldii Rządzącego Senatu w 1861 r. $^{12}$ Od 1819 r. był żonaty z matką Nikołaja - Marią Aleksiejewną Juriewicz (ur. w 1801 r. - zm. w czerwcu 1842 r.). Nikołaj miał kilkoro rodzeństwa: 1) Pawła (ur. w 1820 r. - zm. 9 IV 1874 r.), absolwenta wydziału filologicznego Imperatorskiego Uniwersytetu Kazańskiego, nauczyciela gimnazjum w Orenburgu i w Symbirsku, urzędnika kapituły orderów ministerstwa dworu imperatorskiego; 2) Piotra (ur. w 1824 r. - zm. w 1897 r.), generała-majora artylerii, żonatego z S. Karpową; 3) Jelizawietę (ur. w 1830 r. - zm. po 1858 r.); 4) Jekaterinę (ur. w 1832 r. - zm. po 1881 r.), absolwentkę Instytutu Smolnego w 1848 r., żonę urzędnika w randze rzeczywistego radcy stanu Nikołaja Iwanowicza Annienkowa (ur. 21 IV 1819 r. - zm. 9 VIII 1889 r.), botanika; 5) Michaiła (ur. w 1835 r. - zm. przed 1842 r.); 6) Marię (ur. w 1835 r. - zm. przed 1842 r.); 7) Aleksandra (ur. w 1838 r. - zm. w 1859 r.); 8) Aleksieja (ur. 21 I 1841 r. - zm. po 1842 r.). Żoną Nikołaja Grumm-Grzymajły została w 1864 r. Sofia (ur. po 15 V

11 Российский Государственный Исторический Архив (dalej РГИА), zesp. 37, inw. 7, sygn. 313; sygn. 315; sygn. 337; sygn. 349; sygn. 451; sygn. 529; inw. 46, sygn. 1171, k. 91-93; Archiwum Państwowe (dalej AP) w Kielcach, Akta stanu cywilnego parafii prawosławnej w Kielcach, sygn. 15, s. 40; УПРМФ, 1870, nr 42, s. 603; „Горный Журнал” Nr 8, 1868, s. 19, 21; Nr 5, 1870, s. XXXVIII; $\mathrm{Nr}$ 10, s. II, V; $\mathrm{Nr} 12$, s. X-XI; Nr 4, 1872, s. III; Nr 1, 1873, s. II; Nr 12, 1879, s. V; $\mathrm{Nr} 4$, 1883, s. VI; Nr 12, 1887, s. XLI; „Wiek” Nr 27, 1883, s. 2; Памятная книжка Петроковской губернии на 1872 год, s. 86; Список горным инженерам. Составлен по 1-е Июля 1881 года, Sankt Petersburg 1881, s. 30; Памятная книжка Келеикой губернии на 1886 год, Kielce 1886, s. 94.

12 Сборник дипломных гербов Российского Дворянства, невнесенных в Общий Гербовник. T. IV, s. 84, <https://www.gerbovnik.ru/arms/4507.html> [dostęp grudzień 2017 r.]. 
1827 r. - zm. po 1876 r.), córka chirurga zakładu kamsko-wotkińskiego Sylwestra Fiodorowicza Tuczemskiego i Jelizawiety Awgustowny Mejer. Znamy dwójkę dzieci z tego związku: Jelizawietę (ur. 19 II 1865 r. w zakładzie wotkińskim - zm. po 1876 r.) i Siergieja (ur. 3 II 1866 r. w zakładzie wotkińskim - zm. 1945 r. w Wiedniu). Ów Siergiej był absolwentem Imperatorskiej Szkoły Prawoznawstwa w 1886 r., urzędnikiem ministerstwa sprawiedliwości, a w latach 1890-1914 przebywał na emigracji, gdzie studiował na uniwersytetach w Heidelbergu, Bernie i Paryżu. Po 1905 r. przeszedł na katolicyzm i ukończył Uniwersytet Katolicki w Innsbrucku, a po 1909 r. przyjął święcenia kapłańskie. W 1914 r. był proboszczem kościoła pw. św. Stanisława w Sankt Petersburgu. W 1920 r. służył w rosyjskiej parafii katolickiej w Berlinie. Nikołaj 12 VI 1853 r. ukończył Imperatorski Instytut Górniczy ze stopniem porucznika. Już 18 VI 1853 r. został przyjęty do departamentu górnictwa i oddelegowany do dyspozycji głównego naczelnika uralskich zakładów górniczych, a 10 VIII 1853 r. skierowany do zajęć praktycznych w zakładzie wotkińskim. Po kilku latach (10 IV 1856 r.) został ich nadzorcą, a potem pełniącym obowiązki zarządzającego (14 VI 1860 r.), zatwierdzonym 19 VII 1863 r. W 1870 r. przeszedł na służbę do Królestwa Polskiego i (2 X 1870 r.) dostał stanowisko naczelnika Zachodniego Okręgu Górniczego. W jego liście stanu służby wyraźnie podkreślono, że od 1 XI 1876 r. zdjęto go ze stanowiska z powodu sprzedaży Huty Bankowej. Po dwóch latach na służbie bez etatu (19 VII 1878 r.) na własną prośbę odszedł ze służby z prawem zachowania munduru w stanie spoczynku ${ }^{13}$.

Ostatni na tym stanowisku, Aleksiej Żukowski (ur. 21 XI 1843 r. w guberni petersburskiej - zm. po 1890 r.), był synem urzędnika wyznania prawosławnego. Jego pierwszą żoną (od 1869 r.) była Jelizawieta (ur. przed 1852 r. - zm. między 1875 r. a 1879 r.), córka kapitana II rangi Nikołaja Iwanowicza Odincowa, a drugą (od 1879 r.) Aleksandra (ur. przed 1855 r. - zm. po 1890 r.), córka Wasilija Morgana, architekta z Sankt Petersburga. Znamy czwórkę jego dzieci: Nikołaja (ur. 7 I 1875 r. w Dąbrowie - zm. po 1890 r.), Antoninę (ur. 10 II 1880 r. - zm. po 1890 r.), Ludmiłę (ur. 19 VII 1881 r. - zm. po 1890 r.) i Marię (ur. 8 VI 1883 r. zm. po 1890 r.). Aleksiej Żukowski 1 VI 1864 r. ukończył Imperatorski Instytut Górniczy w Sankt Petersburgu z dyplomem I kategorii i prawem awansu do rangi

\footnotetext{
13 Государственный Архив Пермского Края, zesp. 37, inw. 1, sygn. 55, k. 32v; РГИА, zesp. 37, inw. 46, sygn. 823, k. 121-124v; inw. 74, sygn. 135, k. 60-66; „Горный Журнал” Nr 2, 1868, s. 24-25; $\mathrm{Nr} 4$, 1869, s. IV; $\mathrm{Nr}$ 10, 1870, s. I; Nr 3, 1874, s. I; Nr 8-9, 1878, s. VI; Список горным инженерам за 1871 год, Sankt Petersburg 1872, s. 50; С. В. Голованов, Биографический справочник деятелей русского католического апостольства в эмиграции, Omsk 2005; В. Рыхляков, К истории рода Грум-Гржимайло, „Генеалогический Вестник” Т. 28, 2007.
} 
porucznika korpusu inżynierów górnictwa. Wkrótce (20 VI 1864 r.) został włączony do etatu departamentu górnictwa i oddelegowany do dyspozycji głównego naczelnika uralskich zakładów górniczych, a następnie ( 15 X 1864 r.) do zajęć praktycznych w zakładzie gornobłagodackim. Na własną prośbę przyłączono go do poszukiwań złóż węgla kamiennego na Uralu prowadzonych przez sztabskapitana Chołostowa. Po czym (29 IX 1865 r.) został nadzorcą zakładu wierchniebaranczyńskiego. Jednak po dwóch latach zwolniono go ze służby z przyczyn osobistych. W następnym roku znów wrócił do służby na stanowisko urzędnika do szczególnych poruczeń działu technicznego przy głównym naczelniku uralskich zakładów górniczych. Przełomem w karierze Żukowskiego było skierowanie go na służbę do Królestwa Polskiego, gdzie 7 XI 1870 r. pełnił obowiązki zawiadującego kopalniami węgla kamiennego i cynku w Zachodnim Okręgu Górniczym. Pozostając na tym stanowisku pół roku, podróżował po Francji, Belgii i Niemczech, studiując organizację kopalń węgla kamiennego. Po podporządkowaniu górnictwa Królestwa Polskiego ministerstwu w Petersburgu został (1 XI 1870 r.) pełniącym obowiązki naczelnika Zachodniego Okręgu Górniczego i zawiadującym kopalniami węgla kamiennego. Z tych stanowisk zdjęto go 2 VIII 1878 r. Potem pozostawał na służbie, ale bez stanowiska, ciągle delegowany do pracy w kopalniach prywatnych, gdzie wynagrodzenie otrzymywał od właścicieli lub dzierżawców. Ze służby odszedł 21 II 1890 r. $^{14}$

Po 1878 r. już nie obsadzano stanowiska naczelnika Zachodniego Okręgu Górniczego Królestwa Polskiego, natomiast stanowisko naczelnika Wschodniego Okręgu Górniczego Królestwa Polskiego było obsadzane do końca jego istnienia, co wiązało się z większą liczbą podległych mu zakładów. Na tym stanowisku spotykamy dwie osoby: od 10 V 1866 r. do 24 IX 1870 r. - Jana Hube (Иван Карлович Губе) i pełniącego obowiązki od 25 IX 1870 r. do 1883 r. - Placyda Franciszka Lisickiego (Плацид Франц Мартинович Лисицкий).

Jan Hube, syn Karola, luteranin, urodził się w 1826 r. w Krakowie w rodzinie szlachcica herbu Przeginia. W 1852 r. ukończył Szkołę Górniczą w Liège przy

${ }_{14}$ РГИА, zesp. 37, inw. 7, sygn. 468; inw. 48, sygn. 1316, k. 3-5; inw. 74, sygn. 169, k. 1-6; „Горный Журнал” Nr 4, 1864, s. 65, 67; Nr 7, 1867, s. 9, 11; Nr 3, 1870, s. L; Nr 12, s. VIII; Nr 2, 1871, s. IX-X; Nr 1, 1872, s. VII-VIII; Nr 3, 1874, s. I-II; Nr 12, 1877, s. III; Nr 12, 1878, s. II; Nr 4-6, 189o, s. IX; УПРМФ, 1870, nr 50, s. 732; 1871, nr 7, s. 105; 1874, nr 9, s. VIII; Список горным инженерам за 1871 год, s. 171; Памятная книжка Петроковской губернии на 1872 год, s. 88; Справочная книжка Петроковской губернии на 1877 год, Piotrków 1876, s. 67; Справочная книжка Петроковской губернии на 1878 год, Piotrków 1877, s. 72; Общий морской список, ч. VII, Царствование Александра I, Д-О, Sankt Petersburg 1893, s. 641-642. 
Uniwersytecie w Liège z dyplomem cywilnego inżyniera górnictwa. Majątku nie posiadał. Przed 1861 r. ożenił się z Bronisławą Zimnoch (ur. 1834 r. - zm. po 1867 r.), wyznania katolickiego, córką ziemianina. Z tego związku znamy troje dzieci: 1) Stanisławę Teresę Monikę (ur. 6 XI 1861 r. w Kolonii Meden, parafia Będzin - zm. po 1861 r.), wyznania katolickiego; 2) Karola Cypriana (ur. 5 VII 1864 r. w Hucie Bankowej - zm. po 1864 r.), wyznania katolickiego; 3) Juliana Jana (ur. 1 II 1867 r. w Suchedniowie - zm. po 1898 r.), wyznania katolickiego, chemika, żonatego od 11 IV 1898 r. z Janiną Reginą Ochorowicz (ur. 1876 r. - zm. po 1898 r.). Jego ojciec Karol Hube, syn Michała (ur. 7 II 1769 r. w Toruniu - zm. 23 VI 1845 r. w Krakowie), był wyznania ewangelickiego. Był synem profesora matematyki w Szkole Rycerskiej w Warszawie, Michała Hube, i Doroty Rajcher. Nobilitację uzyskał w grudniu 1790 r. Następnie był profesorem Szkoły Korpusu Inżynierów Litewskich, brał udział w insurekcji kościuszkowskiej i służył w Legionach Henryka Dąbrowskiego, a potem był profesorem Akademii Krakowskiej. Karol Hube ożenił się 16 IX 1816 r. z matką Jana - Anną Zuzanną Marianną Binkiewicz (ur. w 1795 r. w Krakowie - zm. po 1816 r.), wyznania katolickiego, córką Jacentego Binkiewicza, szlachcica, mecenasa przy sądzie najwyższym Królestwa Polskiego, i Magdaleny Eichberger. Bratem Jana był Karol Michał (ur. w 1817 r. w Krakowie - zm. 29 III 1894 r. w Warszawie), wyznania ewangelickiego, szlachcic dziedziczny, absolwent Liceum św. Anny w Krakowie i wydziału prawa Uniwersytetu Jagiellońskiego, doktor prawa, urzędnik sądowy, który m.in. zajmował stanowisko pisarza kancelarii ziemiańskiej i pomocnika sekretarza warszawskiego sądu okręgowego. Był autorem prac: O instytucji hipotecznej w Polsce, Kraków 1840 i O instytucji hipotecznej w Królestwie Polskim, Warszawa 1869. Jego żoną była (od 14 XI 1853 r.) Aniela Brodowska. Znamy jeszcze dwóch ich braci: Michała Jacka (ur. w 1821 r. - zm. po 1844 r.) i Wiktora. Jan Hube po zakończeniu kształcenia został przyjęty 2 I 1856 r. na służbę w departamencie górnictwa Królestwa Polskiego na okres próbny. Jako poddany austriacki potrzebował zgody na służbę w Królestwie, którą uzyskał 4 VIII 1856 r. Pierwsze stanowisko - urzędnika do szczególnych poruczeń przy kopalniach Zachodniego Okręgu Górniczego Królestwa Polskiego - otrzymał 1 IX 1856 r. Po pięciu latach (16 XII 1861 r.) został głównym zawiadowcą pudlingarni (zakładu oczyszczania surówki) i walcowni w Hucie Bankowej, a po następnych pięciu latach (10 V 1866 r.) został mianowany pełniącym obowiązki naczelnika Wschodniego Okręgu Górniczego. Po podporządkowaniu administracji górniczej Petersburgowi w 1870 r. Jan Hube przyjął stanowisko okręgowego inżyniera górnictwa II okręgu nadzoru nad prywatnymi zakładami górniczymi w guberniach Królestwa Polskiego, a 1 IV 1874 r. - okręgowego inżyniera górnictwa I okręgu. W 1887 r. na własną 
prośbę został zwolniony nie tylko ze stanowiska, ale i ze służby z emeryturą. Nie mamy dokładnych danych o miejscu i dacie jego śmierci. Jedyne, co udało się ustalić, to to, że zmarł po $1892 \mathrm{r}^{15}$

Następcą Jana Hube na stanowisku naczelnika Wschodniego Okręgu Górniczego Królestwa Polskiego był Placyd Franciszek Lisicki, który urodził się 23 IX 1833 r. w Płocku. Był katolikiem, synem urzędnika (niektóre źródła wzmiankują o jego szlacheckim pochodzeniu). Ukończył gimnazjum gubernialne w Płocku w $1852 \mathrm{r}$., a następnie w 1858 r. Instytut Agronomiczno-Leśny w Marymoncie. Majątku ziemskiego nie posiadał. Placyd Lisicki był dwukrotnie żonaty, najpierw z Józefą, córką Rocha Busińskiego (ur. przed 1842 r. - zm. 1890 r. w Noworadomsku (Radomsku)), katoliczką. Jego drugą żoną była od 8 VI 1898 r. Wiktoria Marianna, także katoliczka (ur. w 1856 r. w Warszawie - zm. 20 II 1925 r.), córka Ignacego Górskiego, nadzorcy magazynu prowiantowego, i Ludwiki z Więckowskich. Najprawdopodobniej Placyd Lisicki nie miał dzieci. Jego ojciec Antoni Marcin Lisicki (ur. w 1804 r. w Płocku - zm. po 1833 r.) był synem Wawrzyńca (Laurentego) i Salomei Sowińskiej, kancelistą Urzędu Municypalnego miasta Płocka. Jego żoną od 15 VI 1832 r., a matką Placyda, była Franciszka Jankowska (ur. w 1815 r. we Francji - zm. po 1833 r.), córka podoficera Franciszka Jankowskiego i Doroty Piechowskiej. Znamy dwóch braci Placyda: Wiktora Wawrzyńca Justyniana Zachariasza (ur. 25 VIII 1835 r. w Płocku - zm. ?) i Piotra Jana (ur. 13 IX 1837 r. w Płocku - zm. ?). Cała rodzina była wyznania katolickiego. Placyd rozpoczął karierę 13 VIII $1858 \mathrm{r}$. jako uczeń górnictwa, stypendysta Zachodniego Okręgu Górniczego. Niebawem (20 V 1859 r.) dostał stanowisko majstra w hucie w Sławkowie, a następnie (18 II 1860 r.) został pełniącym obowiązki referenta-rachmistrza zarządu Zachodniego

${ }^{15}$ РГИА, zesp. 37, inw. 7, sygn. 118, k. 52-60; sygn. 277; sygn. 313; Archiwum Archidiecezji Częstochowskiej w Częstochowie, Akta stanu cywilnego parafii katolickiej w Będzinie, sygn. Urodzenia 1862-1866, k. 1v, s. 160; AP w Kielcach, Akta stanu cywilnego parafii katolickiej w Suchedniowie, sygn. 43, s. 11; AP w Warszawie, Akta stanu cywilnego gminy warszawskiej VII cyrkułu, sygn. 25, k. 167-167v; Akta stanu cywilnego parafii katolickiej św. Andrzeja w Warszawie, sygn. 100, k. 380v; Akta stanu cywilnego parafii katolickiej św. Krzyża w Warszawie, sygn. 26, k. 202; Akta stanu cywilnego parafii katolickiej św. Aleksandra w Warszawie, sygn. 128, k. 68; „Горный Журнал” Nr 12, 1870, s. X-XI; „Wiek” Nr 27, 1883, s. 2; Памятная книжка Келецкой губернии на 1886 год, s. 91; A. Birkenmajer, Hube Karol, [w:] Polski Słownik Biograficzny. T. 10, z. 1, Warszawa 1962-1964, s. 64-66; K. Mrozowska, Hube Jan Michał, [w:] Polski Słownik Biograficzny. T. 10, z. 1, s. 67-69; W. Sobociński, Hube Karol, [w:] Polski Słownik Biograficzny. T. 10, z. 1, s. 66; M. Nita, Rozwój górnictwa wegla kamiennego w Zagłębiu Dąbrowskim od końca XVIII w. do 1914 r., [w:] Gospodarka nad Przemsza i Brynica od pradziejów do początków XX wieku wświetle badań interdyscyplinarnych, red. D. Rozmus, S. Witkowski, Dąbrowa Górnicza 2009, s. 207-208. 
Okręgu Górniczego. Jego pierwszym stanowiskiem kierowniczym było zawiadywanie wypalaniem węgla drzewnego we Wschodnim Okręgu Górniczym, które objął 30 IX 1867 r. Po podporządkowaniu resortu górnictwa Królestwa Polskiego Petersburgowi zostaje mianowany (25 IX 1870 r.) pełniącym obowiązki naczelnika Wschodniego Okręgu Górniczego. W 1883 r. zdjęto go ze stanowiska i pozostał na służbie przy zarządzie państwowymi zakładami górniczymi w Królestwie Polskim. W latach 9o. XIX w. Lisicki mieszkał w Radomiu, a na początku XX w. był współzałożycielem i prezesem rady nadzorczej Banku Spółdzielczego w Kamiennej, tam też zmarł 11 X $1918 \mathrm{r}^{16}$

Zarządy okręgów górniczych Królestwa Polskiego administrowały: Wschodni - kopalniami rud żelaza, zakładami wypalania węgla drzewnego oraz hutami w Starachowicach, Mostkach, Rejowie, Bzinie, Mroczkowie, Samsonowie, Suchedniowie, Baranowie, Michałowie, Brodach, Nietulisku, Sielpi, Białogonie i Serocku, a Zachodni - kopalniami węgla kamiennego, galmanu (rud cynku) i rud żelaza, pracami poszukiwawczymi, hutami cynku i żelaza w Dąbrowie Górniczej, Sławkowie i Pankach ${ }^{17}$. Wyprzedawanie zarządzanych podmiotów, kopalń i zakładów hutniczych powodowało, że etaty zarządów ulegały ciągłym zmianom. W 1876 r. imperator przychylił się do wniosku Komitetu ds. Królestwa Polskiego o sprzedaży państwowych kopalń węgla kamiennego Ksawery, Cieszkowski i Łabęcki i w ten oto sposób prawie całkowicie ustało państwowe wydobycie tego minerału. W rękach skarbu państwa została tylko nieczynna kopalnia Reden w Dąbrowie (zatopiona od $1865 \mathrm{r}$ ). Taka sytuacja stała się pretekstem do zaprzestania obsadzania stanowiska naczelnika ${ }^{18}$.

Mianowicie, gdy ministerstwu finansów podporządkowywano administrację górniczą Królestwa Polskiego, etaty tej administracji potwierdzono, ale tylko jako tymczasowe. Jednocześnie udzielono stałego mandatu ministrowi na wprowadzanie

16 РГИА, zesp. 37, inw. 7, sygn. 118, k. 71-78, 136-139; AР w Płocku, Akta stanu cywilnego parafii katolickiej Płock, sygn. 12, s. 57; sygn. 14, s. 109; sygn. 18, s. 95; sygn. 22, s. 101; AP w Warszawie, Akta stanu cywilnego parafii katolickiej św. Barbary w Warszawie, sygn. 35, k. 251; Cnpaвочная книжка Келецкой губернии на 1882 год, s. 96; Справочная книжка Келецкой губернии на 1883 год, s. 10о; Памятная книжка Келецкой губернии на 1884 года, s. 102; Inskrypcja z płyty nagrobnej Placyda Franciszka Lisickiego na cmentarzu komunalnym w Skarżysku-Kamiennej; Inskrypcja z płyty nagrobnej Wiktorii Marii z Górskich Lisickiej na cmentarzu komunalnym w Skarżysku-Kamiennej.

17 УПРМФ, 1870, nr 24, s. 353-356; J. Jaros, Organizacja administracji górniczej w Królestwie Polskim, s. 128-129.

18 Историческое обозрение пятидесятилетней деятельности министерства государственных имуществ 1837-1887. Т. 5, Горное дело, Sankt Petersburg 1888, s. 275. 
w nich zmian, jeśli nie będzie to powodowało zmian w budżecie. Minister hr. Piotr Aleksandrowicz Włujew skorzystał z tego uprawnienia. Dostosował struktury urzędowe okręgów górniczych Królestwa Polskiego do zmian przedmiotu zarządzania i ograniczył etat zarządu Zachodniego Okręgu, a zwiększył etat Wschodniego Okręgu. Przy tej okazji (w 1876 r.) zarządzanie państwowymi zakładami górniczymi w obu okręgach Królestwa połączono ze specjalnym stanowiskiem zawiadującego działem górniczym w Królestwie Polskim (заведующий горною частью Царства Польского) ${ }^{19}$. Jego podstawowym zadaniem było czuwanie nad przestrzeganiem prawa górniczego i dbanie o zyski skarbu państwa. Zawiadujący kierował rządowym przemysłem górniczym pod względem administracyjnym, technicznym i naukowym, zajmował się sprawami organizacyjnymi fabryk i warsztatów, rachunkowością i sprawozdawczością budżetową, kontrolą nad porządkiem i bezpieczeństwem, nadzorem nad szpitalami i stowarzyszeniami robotniczymi. Ponadto decydował w kwestiach organizacji struktur urzędowych i pracy podległych mu urzędników i robotników ${ }^{20}$. Zakres decyzji naczelnika wyglądał następująco: a) mianuje i zwalnia urzędników do X kl. włącznie, a wszystkim udziela urlopów krajowych na 29 dni, b) wyznacza terminy, ogłasza licytacje i przetargi na dzierżawy do sumy 5000 rs. w granicach objętych kosztorysem, c) zatwierdza kosztorysy budowlane i techniczne do sumy 600 rs. z możliwością zlecenia ich wykonania, d) zatwierdza protokoły zdawczo-odbiorcze do wysokości 3000 rs., e) nakazuje sprzedaż przez licytację zaległości i braków, z wykreśleniem ich z inwentarza, do wysokości wartości nieruchomości (bez gruntu) 300 rs., (w Królestwie prawo uznawało maszyny za ruchomości, więc nie mógł ich sprzedać), a ruchomości do 600 rs., f) w przypadkach nadzwyczajnych asygnuje na ten cel kwotę nie większą niż 600 rs.

Stanowisko zawiadującego powierzono byłemu (do 1869 r.) naczelnikowi Zachodniego Okręgu Górniczego Królestwa Polskiego inż. Janowi Marianowi Hempelowi $^{21}$ (Иван Мариан Иоакимович Гемпель) (ur. 20 XII 1818 r. w Burcu w obwodzie łukowskim w województwie podlaskim - zm. 8 I 1886 r. w Suchedniowie), katolikowi, synowi oficera i szlachcicowi dziedzicznemu guberni lubelskiej, potwierdzonemu przez heroldię $15 \mathrm{~V} 1851 \mathrm{r}$. Jego ojciec Joachim (ur. 1 IX $1787 \mathrm{r}$. w Puławach - zm. 10 X 1874 r. w Tuchowiczach) posiadał majątek Tuchowicze $\mathrm{w}$ powiecie łukowskim w guberni lubelskiej. Jednak znaczenie rodzina zawdzięcza

\footnotetext{
19 Tamże, s. 31.

20 РГИА, zesp. 37, inw. 7, sygn. 395.

21 Tamże, k. 7-7a.
} 
dziadkowi Jana - Joachimowi Rochowi, który jako włościanin został szwoleżerem gwardii Napoleona w stopniu kapitana, dowódcą szwadronu, a następnie majorem wojsk polskich, właścicielem ziemskim, sędzią pokoju i członkiem Towarzystwa Kredytowego Ziemskiego i Towarzystwa Rolniczego. Z jego małżeństwa z Zuzanną Hoffman urodził się Joachim Hempel. Żoną tegoż Joachima, a matką Jana Hempla, była od 1817 r. Rozalia Dmochowska (ur. ok. 1799 r. - zm. przed 1847 r.). Jan miał siedmioro rodzeństwa: 1) Karola Joachima Feliksa (ur. 18 VIII 1820 r. w Burcu - zm. 5 VII 1885 r. w Tuchowiczach), absolwenta Instytutu Agronomicznego w Marymoncie, dzierżawcę dóbr hr. Aurelego Poletyłły, żonatego z Konstancją Rojkowską; 2) Stanisława Kostkę Adolfa (ur. 5 VI 1822 r. w Burcu - zm. 1 VI 1887 r.); 3) Aleksego Józefa (ur. 1 VII 1823 r. w Burcu - zm. 6 IV 1897 r.), właściciela dóbr Tuchowicze; 4) Joachima Antoniego Józefa (ur. 3 IX 1824 r. w Burcu - zm. ?); 5) Anastazję Annę Zuzannę (ur. 26 XII 1825 r. w Burcu - zm. w 1878 r.); 6) Antoniego Tadeusza (ur. 26 XII 1825 r. w Burcu - zm. 9 IX 1875 r. w Tuchowiczach), dzierżawcę majątku Radawczyk w powiecie lubelskim, żonatego z Marią Czaplicką (ur. w 1829 r. - zm. 7 IV 1895 r.) i 7) Rozalię Annę Mariannę (ur. 20 VII 1832 r. w Tuchowiczach - zm. 13 III 1907 r.), po mężu Niklewicz. Jan Hempel był żonaty dwukrotnie. Jego pierwszą żoną (od 30 X 1847 r.) była Józefa Scholastyka Weissflog (Weissflock) (ur. w 1813 r. - zm. w 1855 r.), wyznania ewangelickiego (wdowa od 1843 r. po Tomaszu Kuczkowskim), córka generała Wojsk Polskich Karola Weissfloga i Józefy Dickert, właścicielka kamienicy w Warszawie. Druga żona (od 5 V 1877 r.) Jana to Leontyna Zabielska (ur. w 1844 r. w Pułtusku - zm. w 1925 r.), katoliczka, córka Józefa Zabielskiego i Antoniny Tołoczek, nauczycielka. Z tych związków urodziło się kilkoro dzieci: 1) Natalia (ur. 8 IX 1848 r. w Dąbrowie Górniczej - zm. po 20 III 1876 r.), katoliczka; 2) Józef Tadeusz (ur. 7 III 1852 r. w Dąbrowie Górniczej - zm. w 1936 r.), katolik, właściciel majątku Choroszczynka; 3) Stanisław (ur. 1 III 1882 r. w Dąbrowie Górniczej - zm. 20 II 1961 r. w Łodzi), po ukończeniu Gimnazjum Męskiego Ronthalera w Warszawie służył w wołyńskim pułku lejbgwardii, dokonał zamachu na naczelnika radomskiego gubernialnego zarządu żandarmerii pułkownika von Płotto, był absolwentem Uniwersytetu w Lozannie, chemikiem; 4) Joachim (ur. 3 I 1884 r. w Dąbrowie Górniczej - zm. w 1955 r.), geolog, uczeń Gimnazjum Męskiego Ronthalera w Warszawie, członek Organizacji Bojowej PPS-Lewica, absolwent uniwersytetów we Fryburgu i w Lozannie, w okresie międzywojennym był związany z przemysłem naftowym w Galicji i współpracował z Państwowym Instytutem Geologicznym. Jan Hempel ukończył Szkołę Wojewódzką Księży Pijarów w Łukowie w 1838 r., a następnie Kursy Dodatkowe Techniczne przy Gimnazjum Gubernialnym w Warszawie 
w 1840 r. i Kursy Techniczne Frąckiewicza, Armińskiego, Janickiego i Adriana Krzyżanowskiego w Warszawie.

Jan Hempel rozpoczął karierę w górnictwie 24 VI 1840 r. jako elew w kopalni Reden w Dąbrowie, by w roku następnym zostać tam pomocnikiem inżyniera mierniczego. W tym czasie, w 1841 r. uległ ciężkiemu wypadkowi w kopalni i wkrótce ( 3 X 1842 r.) został przeniesiony na stanowisko praktykanta departamentu górnictwa komisji rządowej przychodów i skarbu, a potem (18 II 1843 r.) - pomocnika inżyniera-architekta Zachodniego Okręgu Górniczego. Jego pierwszą zupełnie samodzielną posadą było pełnienie obowiązków (od $10 \mathrm{~V} 1847$ r.) markszajdera (mierniczego) i zastępcy naczelnego zawiadowcy kopalń węgla kamiennego i rud żelaza Zachodniego Okręgu Górniczego. Po kilku latach (20 XII 1851 r.) awansował na stanowisko głównego zawiadującego kopalniami węgla kamiennego i rud żelaza w Zachodnim Okręgu Górniczym. W 1857 r. zlecono mu opracowanie mapy geognostycznej Wschodniego Okręgu Górniczego, po czym (28 VI 1860 r.) wrócił na swoje stanowisko. Następnie (20 XII 1860 r.) powierzono mu pełnienie obowiązków naczelnika zakładów górniczych Zachodniego Okręgu Górniczego. W czasie powstania wyjechał do Francji w celu zapoznania się z działalnością tamtejszych kopalń węgla kamiennego. 23 VI 1867 r. został zwolniony ze stanowiska, a 31 I 1868 r. - ze służby państwowej. Jan Hempel przeszedł do pracy w przemyśle prywatnym i w 1868 r. został zarządcą kopalń siarki w Czarkowach pod Nowym Miastem Korczynem, należącej do hr. Ksawerego Pusłowskiego. Do służby rządowej (już rosyjskiej) powrócił w marcu 1876 r. jako inżynier w ministerstwie dóbr państwowych, oddelegowany do dyspozycji departamentu górnictwa ministerstwa finansów. Od razu skierowano go do nadzorowania administracji górniczej w Zachodnim i Wschodnim Okręgu Górniczym Królestwa Polskiego. Wkrótce (15 III 1876 r.) został postawiony nad całą miejscową administracją górniczą jako zawiadujący działem górniczym w Królestwie Polskim. Od 2 VIII 1878 r. jednocześnie pełnił obowiązki naczelnika Zachodniego Okręgu Górniczego Królestwa Polskiego. Z tych stanowisk został zdjęty w $1883 \mathrm{r}$. i pozostawał w etacie zarządu państwowymi zakładami górniczymi w Królestwie Polskim bez stanowiska do 1885 r., kiedy został zwolniony ze służby ${ }^{22}$.

\footnotetext{
${ }^{22}$ РГИА, zesp. 37, inw. 7, sygn. 468; inw. 74, sygn. 178; zesp. 549, inw. 2, sygn. 44, k. 15; AP w Katowicach, Archiwum Górnicze Dąbrowy, sygn. 5258-5259; AP w Kielcach, Akta stanu cywilnego parafii rzymskokatolickiej w Suchedniowie, sygn. 64, s. 135; AP w Lublinie, Akta stanu cywilnego parafii rzymskokatolickiej w Tuchowiczu, sygn. 23, s. 16; Akta stanu cywilnego parafii rzymskokatolickiej w Tucznej, sygn. 1, s. 22; sygn. 10, s. 47; Akta stanu cywilnego parafii rzymskokatolickiej w Wojcieszkowie, sygn. 5, s. 2-3; sygn. 14, s. 56-57; sygn. 16, s. 33; sygn. 17, s. 34;
} 
Jak już wspomniano, od 1878 r. nie obsadzano stanowiska naczelnika Zachodniego Okręgu Górniczego Królestwa Polskiego, a jego kompetencje przejął zawiadujący. Podobnie stało się ze stanowiskiem naczelnika Wschodniego Okręgu Górniczego Królestwa Polskiego od 1883 r. Jednocześnie należy podkreślić, że nadal działały odrębne urzędy - zarządy Wschodniego i Zachodniego Okręgu Górniczego Królestwa Polskiego. Ostatecznie w grudniu 1882 r. zdecydowano, że z dniem 1 III 1883 r. stanowiska zawiadującego działem górniczym w Królestwie Polskim, naczelnika Wschodniego Okręgu Górniczego, architekta i zawiadującego kopalniami Zachodniego Okręgu Górniczego zostaną zastąpione jednym organem naczelnika państwowych zakładów górniczych Królestwa Polskiego (начальник казенных горных заводов Царства Польского) ${ }^{23}$. Na to stanowisko mianowano Wincentego Ignacego Jędrzeja Choroszewskiego, syna Władysława (Викентий Владиславович Хорошевский). Następnie rozporządzeniem z 1887 r. połączono także dotychczas odrębne struktury urzędowe - zarządy okręgów Wschodniego i Zachodniego, przy okazji zmniejszono liczbę stanowisk, a pozostałym podniesiono uposażenie. $\mathrm{W}$ ten sposób przeprowadzono głęboką reformę struktur administracji górniczej Królestwa Polskiego, nie naruszając budżetu.

Wincenty Choroszewski (ur. 4 II 1845 r. w Wilnie, według innych źródeł 4 II 1846 r. - zm. 5 I 1901 r. w Suchedniowie, pochowany na cmentarzu w Wilnie) był katolikiem, szlachcicem herbu Szreniawa, zapisanym do ksiąg rodowych w guberni wileńskiej (zatwierdzonym przez Departament Heroldii Rządzącego Senatu 12 III 1840 r.). Jednak majątku ziemskiego nie posiadał. Jego ojciec Władysław

sygn. 18, s. 31; sygn. 21, s. 2-3; AP w Siedlcach, Akta stanu cywilnego parafii rzymskokatolickiej w Tuchowiczu, powiat Łuków, sygn. 14, s. 195; sygn. 15, s. 191; sygn. 37, s. 103; AP w Warszawie, Akta stanu cywilnego parafii ewangelicko-augsburskiej w Warszawie, sygn. 16, k. 68v; Сnuсок чинам Министерства Государственных Имуществ по 1 Июля 1880 2., Sankt Petersburg 1880, s. 356; Справочная книжка Келецкой губернии на 1882 год, s. 92; Справочная книжка Келеикой губернии на 1883 год, Kielce 1883, s. 96; Памятная книжка Келецкой губернии на 1884 года, s. 102; A. J. Wójcik, Jan Hempel - górnik i geolog - autor „Mapy geognostycznej Zagłębia Węglowego...” (1856 r.), „Prace Naukowe Instytutu Górnictwa Politechniki Wrocławskiej” Nr 17, 2006, s. 349-359; tenże, Jan Marian Hempel - autor map górniczych i geologicznych Królestwa Polskiego, "Analecta” R. 15, 2006, z. 1-2, s. 255-278; tenże, Zachodni Okręg Górniczy. Studia z dziejów geologii i górnictwa w Królestwie Polskim, Warszawa 2008; K. Jurkiewicz, Jan Hempel. (Wspomnienia pośmiertne), „Biblioteka Warszawska” T. 3, 1886, s. 89-92; Z. J. Bzowski, Dzieje rodziny Hemplów spisane we wspótpracy z Kazimierzem Hemplem, Warszawa 1987; Polski wkład w przyrodoznawstwo i technikę. Stownik polskich i związanych $z$ Polską odkrywców, wynalazców oraz pionierów nauk matematyczno-przyrodniczych i techniki. T. 2, H-Ł, red. B. Orłowski, Warszawa 2015, s. 29-32.

${ }^{23}$ Историческое обозрение пятидесятилетней деятельности министерства государственных имуществ 1837-1887. Т. 5, s. 276. 
Choroszewski (ur. 3 IV 1816 r. w Wilnie - zm. 13 V 1871 r. w Wilnie) był urzędnikiem w randze sekretarza kolegialnego i właścicielem folwarku Pomusze w powiecie wileńskim, a matką Amelia Bohdanowicz (ur. w 1819 r. - zm. 21 III 1897 r. w Wilnie). Miał brata Wacława (ur. 14 VI 1850 r. w Wilnie - zm. 4 I 1852 r. w Wilnie). Jego żoną była (od 1877 r.) Celina (ur. w 1853 r. - zm. po 1905 r.), córka ziemianina z powiatu bobrujskiego w guberni mińskiej, Eugeniusza Tadeusza Pruszanowskiego (ur. w 1820 r. - zm. po 1853 r.). Celina Choroszewska po śmierci męża zamieszkała z córką w Warszawie. Dziećmi z tego związku byli: 1) Władysław Eugeniusz Fortunat (ur. 1 VI 1878 r. - zm. po 1935 r.), absolwent Gimnazjum Męskiego w Kielcach i Imperatorskiego Instytutu Górniczego w Sankt Petersburgu, od 1 V 1908 r. technik do spraw działu górniczego i urzędnik do szczególnych poruczeń Zachodniego Okręgu Górniczego, w latach 30. XX w. dyrektor departamentu i górniczo-hutniczego ministerstwa przemysłu i handlu; 2) Eugeniusz Marian (ur. 2 VIII 1880 r. - zm. przed 31 XII 1880 r.); 3) Gustaw Ambroży Wincenty (ur. 8 XII 1884 r. w Suchedniowie - zm. 19 II 1886 r. w Suchedniowie); 4) Celina Elżbieta Anna Petronella (ur. 17 IV 1887 r. w Suchedniowie - zm. po 1918 r.), żona Ludwika Leona Wołodkiewicza, ziemianina mieszkającego w majątku Nowy Dwór w guberni wileńskiej; 5) Wincenty (ur. 15 III 1890 r. w Suchedniowie - zm. po 1918 r.).

Wincenty Choroszewski jako absolwent gimnazjum wileńskiego wstąpił do Imperatorskiego Instytutu Górniczego w Sankt Petersburgu, który ukończył 11 VI 1866 r. z tytułem inżyniera górnictwa. Od razu przyjęto go do służby w departamencie górnictwa ministerstwa finansów, a 29 X 1866 r. został inżynierem departamentu górnictwa Królestwa Polskiego, skąd 19 XI 1866 r. oddelegowano go do zakładów górniczych Królestwa Polskiego w celu zapoznania się z problemami wydobycia węgla kamiennego. Pierwsze stanowisko otrzymał 1 X 1867 r. jako zawiadujący wielkimi piecami hutniczymi w Hucie Bankowej w Zachodnim Okręgu Górniczym Królestwa Polskiego. Po zagranicznych stażach (16 IV 1874 r.) dostał nominację na pomocnika inżyniera górnictwa I okręgu Królestwa Polskiego. Jednak po tym, jak $14 \mathrm{~V} 1876 \mathrm{r}$. skierowano go do pracy w ekspedycji zajmującej się badaniem i osuszaniem błot w guberni mińskiej (23 XII 1876 r.), zwolnił się ze służby. Dwa lata później wrócił do służby, ale już rosyjskiej, w ministerstwie dóbr państwowych, $z$ oddelegowaniem do departamentu górnictwa. Znów przez kilka lat zajmował się badaniem i osuszaniem błot pod kierownictwem generała-majora Josifa Żylińskiego, by po reorganizacji zarządzania działem górniczym Królestwa Polskiego (1 III 1883 r.) objąć stanowisko naczelnika rządowych zakładów górniczych w Królestwie. Po włączeniu działu górniczego Królestwa do Imperium (od 22 II 1895 r.) zachował zwierzchnią władzę już jako naczelnik zarządu 
Zachodniego Obwodu Górniczego Imperium Rosyjskiego. Dopiero 21 XII 1899 r. został zdymisjonowany i włączony do Rady Górniczej. Wincenty Choroszewski oddał duże zasługi przemysłowi górniczemu Królestwa Polskiego. To m.in. dzięki jego staraniom w 1889 r. utworzono szkołę górniczą w Dąbrowie. Był autorem wielu specjalistycznych publikacji i przewodniczył IV i V zjazdowi przedstawicieli przemysłu górniczego w Królestwie Polskim ${ }^{24}$.

Należy podkreślić, że ustrój administracyjny oraz pozycja ustrojowa poszczególnych organów i urzędów administracji górniczej w Królestwie Polskim w latach 1876-1883 należą do najbardziej kuriozalnych, z jakimi można się spotkać w historii administracji. Na taki osąd składa się przede wszystkim dynamiczna relacja między naczelnikami Zachodniego i Wschodniego Okręgu Górniczego Królestwa Polskiego a zawiadującym działem górniczym Królestwa Polskiego, występująca we wspomnianym okresie. Dwa pierwsze organy miały silne umocowanie prawne w postaci ustawy zatwierdzonej przez imperatora i przeprowadzonej przez Radę Państwową. Tymczasem zostały podporządkowane organowi (заведующий горною частью Царства Польского) powołanemu przez ministra na mocy tymczasowego mandatu. Co więcej, organ ten, ów zawiadujący, całkowicie przejął

${ }^{24}$ Центральный Государственный Исторический Архив Санкт-Петербурга (dalej ЦГИАСП), zesp. 963, inw. 1, sygn. 8576; sygn. 10742; Lietuvos Valstybes Istorijos Archyvas, zesp. 391, inw. 7, sygn. 368; РГИА, zesp. 37, inw. 7, sygn. 41; inw. 48, sygn. 866, k. 112; sygn. 1221; sygn. 3025; AP w Kielcach, Akta stanu cywilnego parafii rzymskokatolickiej w Suchedniowie, sygn. 63, s. 12; sygn. 64 , s. 139; sygn. 65, s. 27; sygn. 70, s. 53; AP w Piotrkowie Trybunalskim, Akta stanu cywilnego parafii prawosławnej w Piotrkowie, sygn. 6o, s. 138; AP w Warszawie, Akta stanu cywilnego parafii rzymskokatolickiej św. Aleksandra w Warszawie, sygn. 183, s. 319; Cnucoк горным инженерам. Составлен по 10-е Августа 1891 года, Sankt Petersburg 1891, s. 27; „Gazeta Lwowska” Nr 6, 1900, s. 3; „Wszechświat” $\mathrm{Nr} 4$, 1901, s. 53-54; „УПРМФ” $\mathrm{Nr}$ 28, 1866, s. 552; $\mathrm{Nr} 50$, s. $980 ; \mathrm{Nr} 7,1871$, s. 105; Nr 2, 1873, s. 33-34; Nr 5, s. 100; Nr 44, 1912, s. 795; „Dziennik Warszawski” Nr 256, 1872, s. 1231; „Горный Журнал” Nr 6, 1866, s. 38; Nr 7, s. 23; Nr 10, s. 5; $\mathrm{Nr} 7,1867$, s. 14; $\mathrm{Nr} 4$, 1868, s. 2; Nr 5, 1870, s. XXXVIII; Nr 2, 1871, s. IX-X; Nr 1, 1873, s. V; Nr 12, 1875, s. III; Nr 8-9, 1878, s. 11; Nr 3, 1879, s. II; Nr 12, s. 375-384; Nr 11-12, 1880, s. III; Nr 1, 1883 , s. II; Nr 1, 1885, s. V; Nr 9, 1886, s. VIII; Nr 9, 1889, s. XV; Nr 3, 189o, s. XXVII; Nr 8, 1891, s. L; $\mathrm{Nr} 8,1892$, s. 227 ; Nr 9, 1893, s. 143 ; Nr 6, 1894, s. 111 ; Nr 2, 1895, s. 52; Nr 4, 1897, s. 66-67; Nr 8, 1898, s. 207; Nr 4, 1900, s. 117; Nr 1, 1901, s. 95-96; Nr 1, s. 97-98; Nr 2, s. 22; Nr 9, 1905, s. 144 , 149; Викентий Владиславович Хорочевский, „Известия Общества Горных Инженеров” Nr 1, 1901; Księga adresowa miasta Krakowa i województwa krakowskiego 1932, Kraków 1932, s. 14; Список гражданским чинам четвертого класса. Исправлен по 16-е октября 1896 года, Sankt Petersburg 1896, s. 814; „Przegląd Techniczny” Nr 45, 1913, s. 589; Список лии, окончивщих курс в Горным Институте с 1823 по 1898 год (включительно), Sankt Petersburg 1899, s. 42; Список горным инженерам. Составлен по 25 Марта 1915 2., Piotrogród 1915, s. 273; Список горным инженерам. Составлен по 1 Июня 1892 года, Sankt Petersburg 1892, s. 23. 
kompetencje jednego, a ostatecznie i drugiego naczelnika okręgu. Jednocześnie zachowano odrębne zaplecza urzędowe likwidowanych (zastępowanych) stanowisk naczelników w postaci zarządów. Tak więc organy ustanowione wyższym aktem prawnym zostały potraktowane jak stanowiska urzędnicze. Tym samym rosyjski ustrój administracyjny po raz kolejny dowiódł swojego nieuporządkowania, a właściwie nieprzystawania do norm europejskich ${ }^{25}$.

\subsection{Zarząd Zachodniego Obwodu Górniczego Imperium Rosyjskiego}

Odrębności administracji górniczej Królestwa towarzyszyła odrębność prawna. Taki stan rzeczy można tłumaczyć jedynie brakiem wysoko wyspecjalizowanych kadr rosyjskich. Pamiętajmy bowiem o tezie, że unifikacja i depolonizacja miały jedynie służyć kolonizacji, tu - kolonizacji urzędniczej. W tym jednak wypadku chodziło o niezwykle dochodowy przedmiot zarządzania. Zachodziła więc obawa, że szybkie wprowadzenie rozwiązań i personelu rosyjskiego może negatywnie wpłynąć na poziom dochodów skarbu państwa. Początkowe nastawienie na szybki zysk poprzez prywatyzację przedsiębiorstw okazało się polityką krótkowzroczną. Sytuację polepszyły dopiero dochody z podatków płaconych przez nowo powstające przedsiębiorstwa. Ich masowe powstawanie wiązało się $\mathrm{z}$ rozluźnieniem prawa do ziemi z prawem do wydobywania i przetwarzania kopalin. Warto tutaj wspomnieć, że w przypadku soli Imperium dość szybko przeszło drogę od monopolu przez akcyzę do wolności podatkowej.

Ostatecznie jednak ustawa z 16 I 1895 r. [st.st.] zlikwidowała okręgi górnicze Królestwa Polskiego, jego terytorium włączyła do administracji górniczej Imperium, tworząc z niego Zachodni Obwód Górniczy Imperium Rosyjskiego $\mathrm{z}$ siedzibą w Suchedniowie. Był to jeden z ośmiu obwodów Imperium. Naczelnik Zachodniego Obwodu Górniczego Imperium przejął kompetencje zarządów okręgowych w kwestii górnictwa rządowego i zwierzchnictwo nad dąbrowską szkołą górniczą. Ponadto powierzono mu nadzorowanie górnictwa prywatnego

${ }^{25}$ Patrz szerzej: G. Smyk, Administracja publiczna Królestwa Polskiego w latach 1864-1915, Lublin 2011. 
i w związku z tym podporządkowano okręgowych inżynierów górniczych ${ }^{26}$. W tym samym czasie (1 I 1895 r.) wprowadzono rosyjski podatek górniczy ${ }^{27}$.

Kompetencje naczelnika zarządu Zachodniego Obwodu Górniczego Imperium Rosyjskiego (управление западной горнозаводской области) przedstawiały się następująco: 1) zarząd zakładami rządowymi i nadzór nad prywatnymi pod względem wykonywania praw i przepisów; 2) dbałość o interesy skarbu państwa; 3) prowadzenie spraw sądowych w imieniu skarbu; 4) wspieranie rozwoju prywatnego przemysłu górniczego; 5) nadzór nad terminowym ściąganiem podatków górniczych i zaległości; 5) nadzór nad bezpieczeństwem robót górniczych i stosunkami pracodawców z robotnikami; 6) ogólny nadzór, także nad stroną techniczną robót górniczych, w zakresie przewidzianym przez prawo; 7) techniczny i fiskalny nadzór nad kotłami parowymi w podległych zakładach; 8) rozgraniczanie nadań górniczych wydanych na niezajętych gruntach rządowych; 9) udzielanie koncesji na eksploatację; 10) przyjmowanie zgłoszeń górniczych z planami robót kopalnianych i uzupełnianie ich; 11) wydawanie pozwoleń na budowę zakładów przemysłowych; 12) przyjmowanie oświadczeń o zamiarze sprzedaży udziałów w zakładach wspólnych lub spadkowych; 13) decydowanie o wydzieleniu pojedynczych zakładów z masy wspólnej; 14) nadzór nad wykonaniem zobowiązań przyjętych przez osoby, które na mocy kontraktów z rządem posiadają zakłady rządowe; 15) zbieranie danych statystycznych i przesyłanie ich ministerstwu; 16) rozpatrywanie okoliczności nieszczęśliwych wypadków i wydawanie opinii o przyczynach; 17) nadzór nad realizacją prawa byłej ludności górniczo-fabrycznej zakładów prywatnych; 18) władza zwierzchnia nad personelem urzędniczym (mianują, zwalniają, przenoszą, przedstawiają do nagród itp.); 19) obrona interesów państwa wobec przemysłu prywatnego; 20) wydawanie pozwoleń na poszukiwanie

${ }^{26}$ Nadzór nad przemysłem górniczym prywatnym był sprawowany przez samodzielne stanowiska pod nazwą „inżynier górniczy” oraz ich pomocników i markszajderów (mierniczych). СЗРИ, wyd. 1893 r., t. 7, tytuł II: O przemyśle górniczym prywatnym w guberniach Królestwa Polskiego, art. 334-415 (na podstawie ustawy z 28 IV/10 V 1892 r.). Szerzej na temat nadzoru nad prywatnym przemysłem górniczym w Królestwie patrz: S. Bogdanov, A. Górak, K. Latawiec, J. Legieć, Naczelnicy organów rosyjskiej administracji specjalnej w Królestwie Polskim w latach 1839-1918. T. 3: Ministerstwo Dóbr Państwowych, Lublin 2017.

${ }^{27}$ ПСЗРИ, собрание III, t. 15, 1895, nr 11262, 16 I 1895 r.; Свод Узаконений и Распоряжений Правительства (dalej СУиРП), 1895, poz. 116, O wzmocnieniu nadzoru nad prywatnym przemysłem górniczym i o zatwierdzeniu etatu Zachodniego Zarządu Górniczego. 
złota; 21) wydawanie nadań górniczych na pola złotonośne; 22) nadzór nad eksploatacją lasów górniczych przydzielonych zakładom prywatnym ${ }^{28}$.

Naczelnik Zachodniego Obwodu Górniczego Imperium podlegał bezpośrednio ministrowi, a jego kompetencje prawie pokrywały się z kompetencjami departamentu górnictwa. $\mathrm{W}$ ramach nadzoru nad przemysłem prywatnym był drugą instancją po okręgowych inżynierach górniczych. Mógł zwoływać zjazdy inżynierów okręgowych i mierniczych (markszajderów). Nota bene w Rosji stanowiska markszajderów wprowadzono dopiero 7 III 1877 r. na wzór Królestwa Polskiego.

Naczelnikowi podlegała także szkoła górnicza w Dąbrowie powołana w $1889 \mathrm{r}$. Utworzenia takiej szkoły wręcz żądał zjazd przemysłowców górniczych Królestwa $^{29} \mathrm{w} 1883 \mathrm{r}$. Ze względu na szybki rozwój górnictwa i wprowadzenie zakazu przyjmowania wolnych słuchaczy oraz ograniczenie praw postronnych słuchaczy, a także wprowadzenie limitów przyjmowania słuchaczy pochodzenia polskiego i żydowskiego w szkołach rosyjskich, przemysłowcy wyrazili gotowość finansowania takiej szkoły ${ }^{30}$.

Jednak przede wszystkim naczelnik obwodu górniczego był władzą zwierzchnią dla zarządów górniczych zakładów rządowych. Zatwierdzał plany i kosztorysy wszelkiej działalności, łącznie z pozwoleniami na wyręb lasów ${ }^{31}$.

${ }^{28}$ ПСЗРИ, собрание III, t. 15, 1895, nr 11262; СУиРП, 1895, poz. 116, О wzmocnieniu nadzoru nad prywatnym przemysłem górniczym i o zatwierdzeniu etatu Zachodniego Zarządu Górniczego; СУиРП, 1895, poz. 170, Instrukcja о zastosowaniu art. 334-415 Ustawy górniczej wyd. w 1893 r. o przemyśle górniczym w guberniach Królestwa Polskiego; СУиРП, 1896, poz. 23, 5 I 1896 r., zmiany do tej instrukcji; J. Jaros, Organizacja administracji górniczej w Królestwie Polskim, s. 116-139; tenże, Organizacja rządowej administracji górniczej na Śląsku, s. 187-213; M. Koczanowicz, Prawo górnicze obowiązujące w Królestwie Polskim, Warszawa 1896; W. Łukasiewicz, Korpus górniczy w Okręgu Zachodnim, [w:] Społeczeństwo Królestwa Polskiego. T. 2, red. W. Kula, Warszawa 1966, s. 7-110; A. Okolski, dz. cyt., s. 265-279 (\$ 209); J. Pazdur, dz. cyt., s. $17-38$.

${ }^{29} \mathrm{Na}$ organizację takich zjazdów pozwolił imperator $14 \mathrm{~V} 1882 \mathrm{r}$. na wniosek ministra dóbr państwowych (z 19 IV) zatwierdzony przez komitet ministrów - ПСЗРИ, собрание III, t. 2 (1882), nr 876, мая 14, выс. утв. положение Комитета Министров о разрешении съездов горнопромышленников в Царстве Польском; СУиРП, 1882 г., июля 2, art. 433.

${ }^{30}$ Słownik geograficzny Królestwa Polskiego i innych krajów słowiańskich. T. I, s. 923-925; ПСЗРИ, собрание III, t. 9, 1889, nr 5782, 13 II 1889 r. выс. утв. положение о домбровском горном училище; СУиРП, 1889, art. 265; Историческое обозрение пятидесятилетней деятельности министерства государственных имуществ 1837-1887 (Заведывание горною частью), s. 56.

${ }^{31}$ Сборник законов, распоряжений и разбяснений по вопросам русского фабричного законодательства, red. М. Балабанов, Kijów 1905; Сборник постановлений Главного по фабричным и горнозаводским делам присутствия за 1899-1914 г2., red. В. В. Громан, Piotrogród 1915. 
W 1903 r. zarząd obwodu przeniesiono do Warszawy i wprowadzono zmiany w jego etacie, tworząc stanowisko technika działu górniczego (jednocześnie urzędnika do specjalnych poruczeń) i młodszego referenta, a także przemianowując referenta (radcę prawnego) na starszego referenta i likwidując stanowisko sekretarza. Przy okazji podniesiono wynagrodzenia niektórym urzędnikom oraz zwiększono kredyty na delegacje i najem kreślarzy, laboranta, pisarzy, uczniów górniczych i wydatki gospodarczo-kancelaryjne ${ }^{32}$.

Piastowanie urzędu naczelnika Zachodniego Obwodu Górniczego Imperium Rosyjskiego, jak już pisaliśmy wyżej, powierzono Choroszewskiemu, czyli właściwie tylko przemianowano jego stanowisko. Dopiero po kilku latach (21 XII 1899 r.) naczelnikiem mianowano Rosjanina Nikołaja Michajłowicza Dmitrijewskiego (Николай Михайлович Дмитриевский) (ur. w 1851 r. w guberni niżegorodzkiej - zm. po 12 I 1912 r.), prawosławnego szlachcica bez majątku. Jego ojciec (Michaił Stiepanowicz Dmitrijewski, ur. przed 1831 r. - zm. po 1872 r.) był urzędnikiem w randze radcy dworu. Znamy brata Nikołaja Dmitrijewskiego - Michaiła (ur. w 1845 r. - zm. po 1906 r.), urzędnika, od 1 I 1896 r. w randze rzeczywistego radcy stanu, dyrektora Aleksiejewskiej Szkoły Realnej w Permie. Nikołaj ożenił się z Tatjaną Aleksandrowną Szczedriną (ur. przed 1860 r. - zm. po 1912 r.), z którą miał czworo dzieci: Borisa (ur. 21 VII 1887 r. - zm. po 1912 r.), Wierę (ur. 5 X 1888 r. - zm. po 1912 r.), Olgę (ur. 8 VII 1891 r. - zm. po 1912 r.) i Iwana (ur. 30 III 1893 r. - zm. po 1912 r.). Po gimnazjum w Samarze Nikołaj ukończył Instytut Górniczy w Sankt Petersburgu z dyplomem I kategorii i otrzymał tytuł inżyniera górnictwa (3 VI 1877 r.) z prawem na rangę sekretarza kolegialnego. Niebawem (22 VI 1877 r.) został przyjęty na służbę w departamencie górnictwa i (30 VII 1877 r.) i oddelegowany do zajęć technicznych w zakładach nerczyńskich. Przez kilka lat był naczelnikiem połączonego zerentujsko-kadaszskiego dystansu górniczego, by 24 XII 1880 r. zostać oficerem konwojowym przewozu złota i srebra

32 ПСЗРИ, собрание III, t. 23, 1903, nr 22968; СУИРП, 1903, poz. 972, O przeniesieniu Zachodniego Zarządu Górniczego ze wsi Suchedniowa do miasta Warszawy i o zwiększeniu etatu nazwanego Zarządu. Jednocześnie wprowadzono też kilka innych zmian dotyczących przemysłu górniczego. Patrz: ПСЗРИ, собрание III, t. 23, 1903, nr 2306о, Об утверждении правил о вознаграждении потерпевших вследствие несчастных случаев рабочих и служащих, а равно членов их семейств в предприятиях фабрично-заводской, горной и горнозаводской промышленности; ПСЗРИ, собрание III, t. 23, 1903, nr 23122, Об учреждении старост в промышленных предприятиях; ПСЗРИ, собрание III, t. 23, 1903, nr 22506; СУиРП, 1903, poz. 314, О zmianie statutu emerytalnej kasy inżynierów górniczych; ПСЗРИ, собрание III, t. 23, 1903, nr 23287; СУиРП, 1903, poz. 1121, О trybie i zakresie podporządkowania funkcjonariuszy nadzoru górniczego naczelnikom guberni. 
do Sankt Petersburga. Następnie kilka lat zarządzał karijskimi kompaniami złota i łunżańskimi kopalniami, by 10 III 1885 r. zostać zdjętym ze stanowiska i pozostawać na służbie państwowej na okres jednego roku bez wynagrodzenia, co należy odczytywać jako karę. Potem pracował w zarządzie górnictwem na Uralu i Powołżu. Stamtąd przeniesiono go do Królestwa (21 XII 1899 r.) na stanowisko naczelnika zarządu Zachodniego Obwodu Górniczego. 19 XII 1911 r. został zwolniony na własną prośbę z powodu choroby ${ }^{33}$.

Dmitrijewski odszedł nagle, zapewne dlatego jego następcę mianowano dopiero 5 XI 1912 r. Był nim Dmitrij Michajłowicz Bryłkin (Дмитрий Михайлович Брылкин), który zajmował to stanowisko do końca jego istnienia. Bryłkin (ur. 11 VIII 1857 r. w Orenburgu - zm. po 1920 r.), prawosławny szlachcic dziedziczny bez majątku, był synem Michaiła Dmitrijewicza Bryłkina (ur. w 1826 r. - zm. po 1857 r.), absolwenta wydziału prawa Imperatorskiego Uniwersytetu Petersburskiego ze stopniem kandydata prawa, urzędnika departamentu komisariackiego ministerstwa wojny, a następnie głównej składowej komory celnej w Warszawie. Tak więc ojciec Dmitrija także miał związki z Królestwem Polskim (choć jego syn urodził się już w czasie służby w Orenburgu), na stanowisku urzędnika do szczególnych poruczeń przy naczelniku orenburskiego okręgu celnego. Matką Dmitrija była Adelaida Osipowna (ur. przed 1835 r. - zm. po 1857 r.), kalwinistka, której panieńskiego nazwiska nie znamy. Dmitrij Bryłkin ukończył w 1881 r. Imperatorski Instytut Górniczy $\mathrm{z}$ tytułem inżyniera górnictwa i prawem awansu na rangę sekretarza kolegialnego przy wstąpieniu na służbę. W 1882 r. ożenił się z córką kapitana Aleksandrą Nikołajewną Tumkowską (ur. przed 1864 r. - zm. po 1915 r.), z którą

${ }^{33}$ ЦГИАСП, zesp. 963, inw. 1, sygn. 8742, k. 1-5; Государственный Архив Пермского Края, zesp. 37, inw. 1, sygn. 506, k. 30v-31; inw. 6, sygn. 348, k. 76v-77; РГИА, zesp. 37, inw. 48, sygn. 866; sygn. 2084, k. 70-70v; AP w Kielcach, Akta stanu cywilnego parafii prawosławnej w Kielcach, sygn. 68, k. 34; УПРМФ, 1911, nr 15, s. 289; „Gazeta Lwowska” Nr 6, 1900, s. 3; „Горный Журнал” Nr 10, 1885, s. VII; Nr 6, 1886, s. XXXVIII; Nr 12, s. XVII; Nr 3, 189o, s. XXVII-XXVIII; Nr 4-6, 1891, s. IX; $\mathrm{Nr}$ 1, 1892, s. 8; Nr 9, 1893, s. 141; Nr 7, 1895, s. 177; Nr 1, 1896, s. 7-8; Nr 1, 1897, s. 7; Nr 4, 1898 , s. 51-52; $\mathrm{Nr} 4$, 1900, s. $117 ; \mathrm{Nr} 3$, 1901, s. $58 ; \mathrm{Nr} 6$, 1902, s. $152 ; \mathrm{Nr} 9$, 1903, s. $252 ; \mathrm{Nr}$ 5, 1905, s. 87; $\mathrm{Nr} 3$, 1911, s. 39; $\mathrm{Nr}$ 4-5, 1912, s. 101; Список гражданским чинам четвертаго класс. Исправлен по 1-е Марта 1907 года, Sankt Petersburg 1907, s. 1103; Список горным инженерам. Составлен по 1 Июня 1892 года, s. 85; Список гражданским чинам четвертого класса. Исправлен по 1-е Сентября 1906 года, Sankt Petersburg 1906, s. 338, 827; Список лии, окончивших курс в Горным Институте с 1823 по 1898 год (включительно), s. 53; Список горным инженером. Составлен по 2 Апреля 1906 года, Sankt Petersburg 1906, s. 13; Список горным инженерам. Составлен по 15 Мая 1908 года, Sankt Petersburg 1908, s. 14; Список горным инженерам. Составлен по 15 Мая 1909 года, Sankt Petersburg 1909, s. 13; Список горным инженерам. Составлен по 1 Июня 1910 2oda, Sankt Petersburg 1910, s. 13. 
miał kilkoro dzieci: Lidię (ur. w 1883 r. w Niżnym Tagile - zm. po 1915 r.), Marię (ur. 2 IV 1886 r. w Niżnym Tagile - zm. po 1915 r.), Michaiła (ur. 21 V 1888 r. w Jekaterynburgu - zm. po 1915 r.), Olgę (ur. 9 II 1890 r. w Dąbrowie Górniczej zm. po 1915 r.), Warwarę (ur. 5 XII 1891 r. w Dąbrowie Górniczej - zm. po 1915 r.), Siergieja (ur. 29 I 1896 r. w Sankt Petersburgu - zm. 28 VI 1938 r. w Leningradzie), późniejszego wykładowcę Wyższej Szkoły Kawalerii (od 1920 r.), aresztowanego i rozstrzelanego z wyroku NKWD w 1938 r. Bryłkin początkowo służył na Uralu, ale już 1 VIII 1889 r. został naczelnikiem dąbrowskiej szkoły górniczej, a $7 \mathrm{~V}$ 1899 r. - pomocnikiem naczelnika zarządu Zachodniego Obwodu Górniczego. Po odejściu Dmitrijewskiego dostał nominację na stanowisko naczelnika zarządu Zachodniego Obwodu Górniczego, które zajmował do jego likwidacji w $1917 \mathrm{r}$. W 1920 r. Bryłkin pracował na stanowisku pomocnika ds. administracyjnych w Moskiewskiej Akademii Górniczej ${ }^{34}$.

\section{Podsumowanie}

Administracja górnicza Królestwa Polskiego jawi się jako wyjątkowa ostoja polskości. Co prawda już w 1870 r. zostaje podporządkowana rosyjskiemu ministerstwu

${ }^{34}$ ЦГИАСП, zesp. 963, inw. 1, sygn. 13013; РГИА, zesp. 23, inw. 3, sygn. 116; zesp. 1349, inw. 5 , sygn. 2505, s. 1-6; sygn. 3085, knlb.; Archiwum parafii prawosławnej w Częstochowie, Akta stanu cywilnego parafii prawosławnej w Częstochowie, sygn. 1890 r., k. 7v-8; Archiwum parafii prawosławnej w Sosnowcu, sygn. 189 o r., k. 12; sygn. 1891 r., k. 20v-21; sygn. 1896 r., k. 7v-8; Cnucoк горным инженерам. Составлен по 25 Марта 1915 2., s. 13; „Горный Журнал” Nr 1, 1885, s. V, VII; $\mathrm{Nr} 3$, 1887, s. LIII; Nr 11-12, 1889, s. XV; Nr 4-6, 1891, s. XI; Nr 1, 1892, s. 8; Nr 4, 1893, s. 42-44; $\mathrm{Nr} 6$, 1894, s. 114 ; $\mathrm{Nr} 1$, 1896, s. 7-8; Nr 5, s. 105; Nr 6, s. 145; Nr 7-8, 1899, s. 251; Nr 2, 1900, s. 44; $\mathrm{Nr} 4$, s. $124 ; \mathrm{Nr} 8$, 1901, s. 217 ; $\mathrm{Nr}$ 9, 1903, s. 253; $\mathrm{Nr} 1$, 1908, s. 9; $\mathrm{Nr} 3$, 1913, s. 31; $\mathrm{Nr} 8$, s. 144-145; $\mathrm{Nr} 11-12$, s. 231; „УПРМФ” $\mathrm{Nr}$ 13, 1909, s. 221; $\mathrm{Nr} 12,1915$, s. 210; Список тии, окончивщих курс в Горным Институте с 1823 по 1898 год (включительно), s. 62; Календарь Пермской губернии на 1887 г., Реrm 1886, s. 47; Список гражданским чинам четвертого класса. Исправлен по 1-е сентября 1906 года, s. 1787; Список гражданским чинам четвертаго класса. Исправлен nо 1-е Mapma 1916 года, Piotrogród 1916, s. 937; Список горным инженерам. Составлен по 10-е Августа 1891 года, s. 146; Список горным инженерам. Составлен по 1 Июня 1892 года, s. 134; Список горным инженером. Составлен по г Апреля 1906 года, s. 37; Список горным инженерам. Составлен по 15 Мая 1908 года, s. 26; Список горным инженерам. Составлен по 15 Мая 1909 года, s. 24; Список горным инженерам. Составлен по 1 Июня 1910 года, s. 23, 3о; А. Мокеев, Горное дело в Царстве Польском: исторический опыт организации горнотехнического образования, „Rocznik Instytutu Polsko-Rosyjskiego” Nr 2, 2012, s. 22; tenże, Международное сотрудничество в сфере горного образования в Европе в ХІХ веке (на примере Германии и России), „Новый Университет” Nr 3, 2014, s. 66. 
w Petersburgu, ale nie poszły za tym dalsze działania rusyfikacyjne, jak w przypadku innych działów administracji Królestwa. Przede wszystkim zachowano polskie prawo górnicze i ustrój administracji górniczej. Powołanie wydziału ds. górnictwa polskiego w departamencie górniczym w Petersburgu było jedynie podkreśleniem tej odrębności. Dopóki ani prawo, ani struktury nie zostały zmienione, nie było otwartej drogi dla urzędników rosyjskich do służby w tej administracji. Wydaje się, że rosnąca rola resortu finansów i skarbu Imperium Rosyjskiego zdecydowała, że czynniki natury politycznej przegrały z ekonomicznymi. Władze mogły się obawiać, że gwałtowne zmiany obsady personalnej pociągną obniżenie jakości zarządzania i spadek dochodów. Dopiero w $1895 \mathrm{r}$. włączono Królestwo Polskie do rosyjskiej administracji górniczej, tworząc z jego terytorium Zachodni Obwód Górniczy Imperium Rosyjskiego, a jeszcze później w ostatnich dniach XIX wieku - na czele tej administracji postawiono Rosjanina.

Pozycję opisanych naczelników dobrze uzupełnia informacja o ich zarobkach. Trzeba jednak pamiętać o ponad 30 latach, które minęły od 1870 do 1895 r.

\begin{tabular}{|l|c|c|c|}
\hline \multicolumn{1}{|c|}{ Nazwa etatu } & $\begin{array}{c}\text { Wynagrodzenie } \\
\text { zasadnicze }\end{array}$ & Dodatki & Ogółem \\
\hline $\begin{array}{l}\text { Naczelnik wschodniego okręgu Królestwa } \\
\text { Polskiego (1870) }\end{array}$ & $1500,-$ & $450,-$ & $1950,-$ \\
\hline $\begin{array}{l}\text { Naczelnik zachodniego okręgu Królestwa } \\
\text { Polskiego (1870) }\end{array}$ & $2600,-$ & $450,-$ & $3050,-$ \\
\hline $\begin{array}{l}\text { Naczelnik Zachodniego Obwodu Górniczego } \\
\text { Imperium Rosyjskiego (1895) }\end{array}$ & 2500 & 2300 i 1200 & 6000 \\
\hline
\end{tabular}

Charakterystyczne jest także to, że stolicą tego działu administracji był aż do 1903 r. Suchedniów, a nie stolica władz rosyjskich - Warszawa, czy choćby któreś $\mathrm{z}$ miast gubernialnych. 


\section{Summary}

\section{Heads of the Russian mining administration in the Kingdom of Poland}

The article presents the transformation of the structure of the Russian administration of mining on the western outskirts of the Russian Empire, in the Kingdom of Poland. The authors describe the circumstances of the subordination of local administration government mining to the Ministry of Finance of the Russian Empire, and then describe the structural, territorial and legal changes of this administration. The key part of the article is the presentation personalities of the heads of the mining administration of the Kingdom of Poland.

KEYwords: The Russian Empire, the Kingdom of Poland, the $19^{\text {th }}$ century, mining industry, mining administration, officialdom, managers of mining, bureaucracy. 